\title{
DRYING OF THOMPSON SEEDLESS GRAPES IN THIN-LAYER USING A BIOGAS DRYER
}

\author{
Zayed M. F. ', S. S. Kassem ${ }^{1}$, H. A. Awad ${ }^{2,3}$, \\ I. N. Nassar $^{4}$ and E. F. Aboukila ${ }^{5}$
}

\begin{abstract}
A biogas dryer was developed to study experimentally drying behavior of Thompson seedless grapes under Alexandria Governorate, Egypt conditions. Drying experiments are carried out in the month of August 2016. During the experimentation, temperatures of air at various places in the dryer, ambient relative humidity and humidity variation in drying chamber and mass of the dried grape are measured on hourly basis. four $\mathrm{kg}$ of Thompson seedless grapes are dried in forced convection heat transfer mode from initial moisture content of $79 \%(\mathrm{wb})$ to final moisture content $14 \%(w b)$ in 44 hours. The drying was carried out under uncontrolled condition. The average drying chamber temperature was around $51.98{ }^{\circ} \mathrm{C}$. The biogas burner efficiency was $62.06 \%$. The effect of heating source on color change of the dried grapes was investigated. Color data were obtained using a high-resolution digital camera and lighting box and the images were analyzed quantitatively using Photoshop to get the L, $a$ and $b$ in the Histogram Window. Statistical analysis showed that there was a significant effect of heating source on color data of the dried grapes. Regardless of the heating source, all raisins had varying degrees of brown coloring. The dried grapes by the biogas dryer had lower browning index (BI) of 43.52 indicating good quality. It could be concluded that the farmers can use biogas energy to enhance its utilization to produce good quality raisins
\end{abstract}

Keywords: Drying, biogas energy, grapes, raisins.

\footnotetext{
${ }^{1}$ Researcher, Agric. Eng. Res. Inst., Agric. Res. Centre, Dokki, Giza, Egypt.

${ }^{2}$ Lecature, Dept. of Agric. Eng., Fac. of Agric., Omar Al Mukhtar Univ., Al Bayda, Libya.

${ }^{3}$ M. Sc. Student, Dept. of Natural Resources \& Agric. Eng., Fac. of Agric., Damanhour Univ., Egypt.

${ }^{4}$ Prof., Dept. of Natural Resources \& Agric. Eng., Fac. of Agric., Damanhour Univ., Egypt.

${ }^{5}$ Assist. Prof., Dept. of Natural Resources \& Agric. Eng., Fac. of Agric., Damanhour Univ., Egypt.
} 


\section{INTRODUCTION}

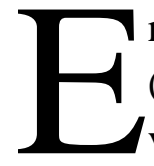

nergy is a key factor for the growth and development of a country (Alemneh, 2011). In order to solve the energy problem for villages in rural areas in Egypt, several renewable energy technologies have been initiated such as solar energy and biogas technology. However, biogas has been proved to be viable and emerged as a promising energy technology. It has been one of the most successful technologies for the production of clean, environmental friendly, cost effective sources of energy and has multiple benefits (Baral et al., 2013). Egypt took serious steps to produce biogas to be an energy source. However, Egyptian researchers have developed different techniques to produce biogas from animal wastes and also from different agricultural wastes to be an energy source for farmer houses applications (El- Shimi, 1994; Rihan, 2013). Moreover, $40 \%$ of the amounts of agricultural residues and animal wastes which were utilized in biogas production could produce energy and the rest percentage is biogas by-products (Helmy et al., 2003).

The biogas is a sustainable and renewable energy source that can provide green energy, a better environment and new jobs (Lantz et al., 2007). The advantages of biogas as a renewable source of energy are cleanness and produce no pollution when burning (Cvetkovic et al., 2014). Biogas can be used as vehicle fuel in buses, distribution tracks and passenger cars and it is mainly used for heat or combined heat and power (Lantz et al., 2007). Pastorek et al. (2004) stated that biogas contains $50-75 \%$ of methane, $25-50 \%$ of carbon dioxide and adulterants of minor gas such as hydrogen sulphide.

Grape is one of the most popular and palatable fruits in the world. It has about 78 percent water. Meanwhile, raisins (dried grapes) contain only about 15 percent water. The raisins could be produced by drying fresh grapes, either by direct sun drying, shade drying or hot air drying (Pangavhane and Sawhney, 2002). Thompson seedless raisins contain approximately $67 \%$ to $72 \%$ sugars by weight, most of which is fructose and glucose. They also contain about 3\% protein and 3.5\% dietary fiber (Dong et al., 2013). Producing raisins using both biogas and solar energies is a 
contribution to the high demand on renewable energies for a sustainable world (Ramos et al., 2015).

There are different conditions like drying air temperature, air flow rate, dryer design, etc. that have influence on the drying efficiency. However, the maximum allowable drying temperature for grapes is $65^{\circ} \mathrm{C}$. If this limit is exceeded, skin damage may occur, and color of the products get darkened (Oztekin et al., 1999). Pangavhane et al. (1999) dried grapes at a drying air temperature of $60^{\circ} \mathrm{C}$. Di Matteo et al. (2000) carried out drying experiments of seedless white grapes in a convection oven at $50^{\circ} \mathrm{C}$, with an air speed of $0.5 \mathrm{~m} / \mathrm{s}$. Sharma et al. (1992) found that the temperature rise in the cabinet dryer was $25-30^{\circ} \mathrm{C}$ over that of the ambient. Pangavhane et al. (2002) developed a natural convection solar dryer where the average temperature between 50 and $55^{\circ} \mathrm{C}$ was obtained, which was optimum for the grapes drying process. Azzouz et al. (2002) mentioned that during the tests of drying grapes, the temperature varied from 50 to $70{ }^{\circ} \mathrm{C}$, the air humidity from $10 \%$ to $30 \%$ and the velocity of drying air from 1.0 to $2.3 \mathrm{~m} / \mathrm{s}$. Doymaz and Pala (2002) finished the drying for seedless grapes when the final moisture content was $20 \%$ (on dry base) and Yaldiz et al. (2001) dried grapes from initial moisture content ranged from 260 to $330 \%$ (on dry base) to a final moisture content of $16 \%$ (on dry base). Also, Karathanos and Belessiotis (1999) dried grapes of two varieties resulting in either dried Sultanas (goldencolored raisins) or currants (small black to deep-purple raisins). The initial moisture content of these materials was in dry basis: sultana grapes, $300 \%$; currant grapes, $280 \%$.

Moy et al. (1985) constructed an S-shaped heat exchanger to allow ambient air to be heated by combusting methane. The heated air was admitted to the solar dryer whenever solar energy was unavailable. Biogas to the ignitor and burner was activated by a thermostat set at $49{ }^{\circ} \mathrm{C}$ inside the dryer. Total drying times for papaya (6.4 $\mathrm{mm}$ thick), banana $(6.4 \mathrm{~mm})$ and pineapple $(10 \mathrm{~mm})$ slices at a loading density of 4.7 plus or minus $0.3 \mathrm{~kg} / \mathrm{m}^{2}$ varied from 11 to $16 \mathrm{hrs}$ in both the solar-only and solarbiogas dryers. However, drying of solar-biogas was completed in one day while the solar-only system required 1.5 to 2 sunny days. The qualities of dried fruits in the hybrid system were better than those in the only solar 
system. Hahn et al. (2011) reported that Calyxes were dried in 4.5 hours at $70^{\circ} \mathrm{C}$ with a hybrid solar biogas system. One $\mathrm{kg}$ of biogas was burned per kg of dried product. Sona (2015) developed a flat plate solar collector with a fan connected and an auxiliary heating unit using biogas for crop drying purposes. Corrêia et al. (2016) evaluated the use of thermal energy from the burning biogas for heating air and its potential use in a drying chamber. The heating system proposed has proved to be effective for drying different species of medicinal plants, since it meets the temperature range specified in the literature. The objective of this study was to test and evaluate the drying of Thompson seedless grapes in thinlayer using a biogas dryer.

\section{MATERIALS AND METHODS}

\section{Characteristics of seedless grape samples}

In this study, fresh Thompson seedless grapes were brought from the local market (Bakous, Alexandria Governorate, Egypt) during the summer season of 2016. The grapes were examined to avoid contamination by bacteria or fungi. The grapes were cleaned with fresh water. They were subjected to physical characteristics measurements: berry weight, bulk density and diameter. These measurements and all drying experiments were conducted at the Tractors and Farm Machinery Testing \& Research Station at Sabahia, Alexandria Governorate, Egypt. The station lies between latitude $30.76^{\circ} \mathrm{N}$ and longitude $29.696^{\circ} \mathrm{E}$.

One $\mathrm{kg}$ of fresh Thompson Seedless grapes of the selected size was subjected to physical characteristics measurements. The physical characteristics of the grapes included fruit weight, shape, volume, density and diameter. The particle mass was measured by digital balance. The diameter of the grapes was measured using a Vernier Calliper. The particle volume was measured using water displacement technique. The particle density was calculated by dividing particle mass over particle volume. Table (1) depicts the physical characteristics of the fresh Thompson seedless grapes used in the drying experiments. The chemical analyses were determined at Food Science and Technology Department, Faculty of Agriculture, Alexandria University. The chemical analyses included crude fiber, total sugar, total soluble solids (TSS) and citric acid 
of fresh grapes. Table (1) depicts the chemical characteristics of fresh Thompson Seedless grapes used in the drying experiments. For determining initial moisture content, four samples of fresh grapes were dried in electric oven according to standard methods and the average value is shown in Table (1).

\section{Chemical pretreatment}

The fresh seedless grape was washed with pure water to eliminate extraneous matter adhering to fruits. The grapes were blanched by dipping in a heated solution to about $80{ }^{\circ} \mathrm{C}$ which contained $50 \mathrm{ml} /$ liter water of $1 \%$ sodium hydroxide for $30 \mathrm{~s}$. The blanched grapes were immediately washed by immersing in cold water, and then immersed in citric acid with $50 \mathrm{ml}$ per 2 liters of water. The grapes were washed with tape water to be free of alkaline. The objective of this process was to create cracks in the surface of the waxy peel for increasing the drying rate (Kassem, 2007). Finally, blowing with air for about 5 minutes was achieved to eliminate excess water from the surface. The sulfur powder was burned in a sulfuring cabinet $\left(0.11 \mathrm{~m}^{3}\right)$ for 4 hours to sulfur the grapes, however, ( $2 \mathrm{~g}$ raw sulfur/ $1 \mathrm{~kg}$ grapes) was utilized as reported by Athanasopoulos and Thanos (1998), however, Tlay et al. (2014) applied this amount in their experiment during grapes drying process. The objective of this process is to prevent enzymatic and non-enzymatic browning reactions, which are detrimental for color and flavor.

Table (1). Physical and chemical characteristics of the fresh Thompson seedless grapes used in the drying experiments.

\begin{tabular}{|l|c|}
\hline \multicolumn{1}{|c|}{ Items } & Values \\
\hline Physical characteristics & 2.25 \\
\hline Average mass $(\mathrm{g} /$ particle) & 1.37 \\
\hline Average volume $\left(\mathrm{cm}^{3} /\right.$ particle) & 45 \\
\hline Average mass of 20 particles $(\mathrm{g})$ & 68 \\
\hline Average volume of 50 particles $\left(\mathrm{cm}^{3}\right)$ & 79 \\
\hline Average initial moisture content $(\%$ wet base) & 78.5 \\
\hline Chemical characteristics & 0.46 \\
\hline Average total sugar $(\%)$ & 0.65 \\
\hline Average crude fiber $(\%)$ & 21.5 \\
\hline Average citric acid $(\%)$ & \\
\hline Total soluble solids $\left({ }^{\circ}\right.$ Brix) & \\
\hline
\end{tabular}


All pre-drying treatments were achieved at the evening about $7 \mathrm{pm}$ preceding the drying experiment and the treated grapes were stored in plastic bags in a refrigerator at $7{ }^{\circ} \mathrm{C}$ until the next morning at 8 am (13 hours). The samples were removed from the refrigerator and kept in the room temperature for an hour before drying process. The desired final weight of dry grapes was calculated according to Brennand (1994). All weighing processes during the drying experiments were completed in less than $10 \mathrm{~s}$.

\section{Drying method and procedures}

The drying experiments were carried out indoor between 9 and 17 of August 2016 under Alexandria, Egypt. The drying was considered to be a forced convection type dryer where the fan was utilized to drive the drying air flow through the drying chamber. The photo and schematic diagram of the utilized biogas dryer are shown in Fig. (1) and Fig. (2), respectively.

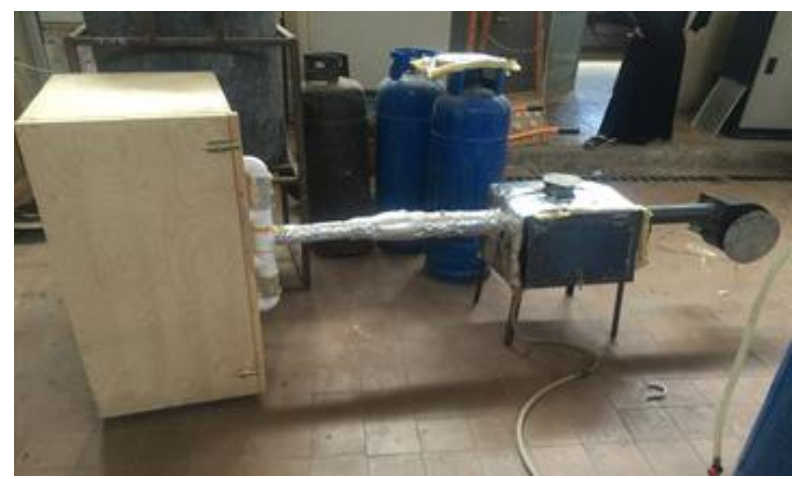

Fig. (1). Photo of the biogas dryer

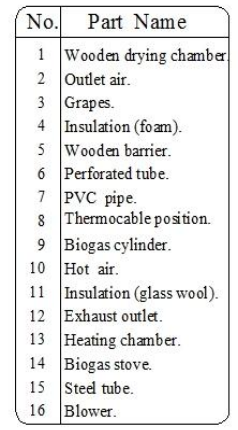

Dims. in $\mathrm{cm}$.

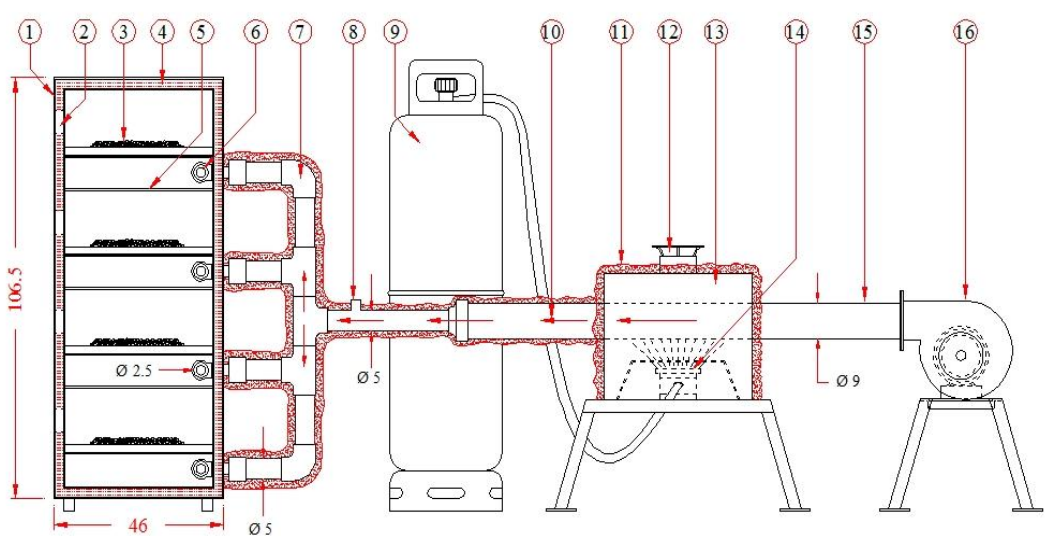

Fig. (2). Schematic of the biogas dryer 
Thin layer drying experiment was considered in this study and the packing density of the drying trays was about $5.2 \mathrm{~kg} / \mathrm{m}^{2}$. Yaldiz et al. (2001) reported that in a solar dryer, the packing density of the drying tray was $6.25 \mathrm{~kg} / \mathrm{m}^{2}$ for thin layer drying experiments of grapes. The air velocity was measured by using a portable digital anemometer (EXTECH Model) and adjusted to be $1.21 \mathrm{~m} / \mathrm{s}$. over the surface of each dring tray (Kassem, 2007).

The drying chamber was divided into four parts and each part carried a tray and there were wooden shelves to prevent air passing to each drying part. Each drying part had a try holding one $\mathrm{kg}$ of the fresh grapes. The drying experiment was continued until the grapes achieved a final moisture content around $14 \%$ wb (Yaldiz et al., 2001). The experiments were continued to about $12 \mathrm{~h}$ every day then continued in the next day. During each trial, the weight of the grapes on the trays was recorded hourly by removing it from the drying chamber for approximately 15-20 seconds.

Tdi, Tdc, and Tdo were the temperature distribution in the heating locations as shown in Fig. (3). Tdi is the temperature at the inlet of drying chamber. Tdc is the temperature inside the drying chambers. Tdo is the temperature at the outlet of drying chambers, respectively. Calibrated type $-\mathrm{K}$ thermocouples were used to measure the temperature.

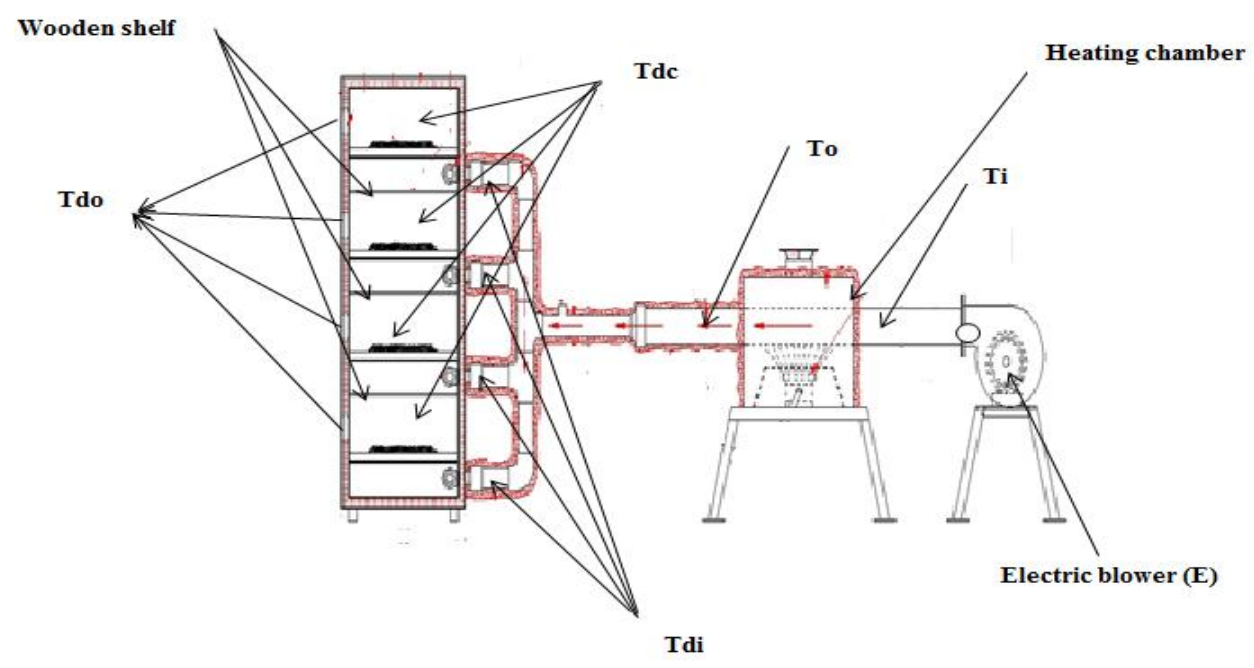

Fig. (3). Temperature distribution in the biogas dryer 
The relative humidity of the air inside the drying chamber and temperature were measured by a hand held relative humidity device. It is a digital hygrometer thermometer dew point (model Control Company, made in USA). The utilized biogas was produced locally through the digester located at the Tractors and Farm Machinery Testing \& Research Station at Sabahia, Alexandria Governorate, Egypt (El-Bakhshwan et al., 2015). The biogas was stored in cylinders at pressure of 15 bar. Each compressed cylinder was approximately $0.900 \mathrm{~m}^{3}$. It has a calorific value of $25 \mathrm{MJ} / \mathrm{m}^{3}$ as methane gas $\left(\mathrm{CH}_{4}\right)$ of $60-70 \%$.

\section{Data analysis}

\section{a. Moisture content calculations}

The moisture content of the dried grapes was determined using the following equation (Ghanem, 2002):

$$
M_{t}=\left[\left(\frac{W_{t}}{W_{i}}\right) \times\left(1+M_{i}\right)-1\right] \ldots \ldots \ldots \ldots \ldots \ldots \ldots \ldots \ldots \ldots \ldots \ldots \ldots \ldots \ldots \ldots \ldots
$$

Where: $M_{i}$ is initial moisture content of the grapes (decimal, on dry base), $M_{t}$ is The moisture content of the grapes at any time $\mathrm{t}$ (decimal, on dry base), $W_{i}$ is initial weight of the grapes (g) and $W_{i}$ is the weight of the grapes at any time $\mathrm{t}(\mathrm{g})$.

\section{b. Raisins quality by color analysis}

In this study, the color of the dried grapes was measured using a simple digital imaging method (Yam and Papadakis, 2004). The dried grape was put in a white container inside a lighting box and it was illuminated by two lighting $26 \mathrm{~W}$ fluorescent lamps as light source (lumen $=1250+/-20 \%$ ). All lamps (13 cm long) were situated $45 \mathrm{~cm}$ above the dried grapes sample. A high-resolution digital camera (Canon XUS105, 12.0 Megapixel, 4 digital zoom) was used. A laptop computer (Acer T6500, 4.0 GB RAM, 320 GB hard disk) was used to store images. The digital camera was located vertically over the background at a distance of $45 \mathrm{~cm}$. The angle between the camera lens and the lighting source axis was approximately $90^{\circ}$. The camera was fixed on the top of the lighting box Fig.(4) which was constructed from white plastic.

Four dried grapes images were captured and an example of them is illustrated in Fig. (5). The images color was analyzed quantitatively using 
Photoshop (Adobe Systems, 2002). The Histogram Window of Photoshop used to determine the color distributions along the $\mathrm{x}$-axis and y-axis.

The Histogram Window displays the statistics (mean, standard deviation, median, percentage, and so on) of the color value lightness (L). The Histogram Window can also display the statistics for the two other color values ( $a$ and $b$ ), which is done by selecting $a$ and $b$ under the Channel drop-down menu

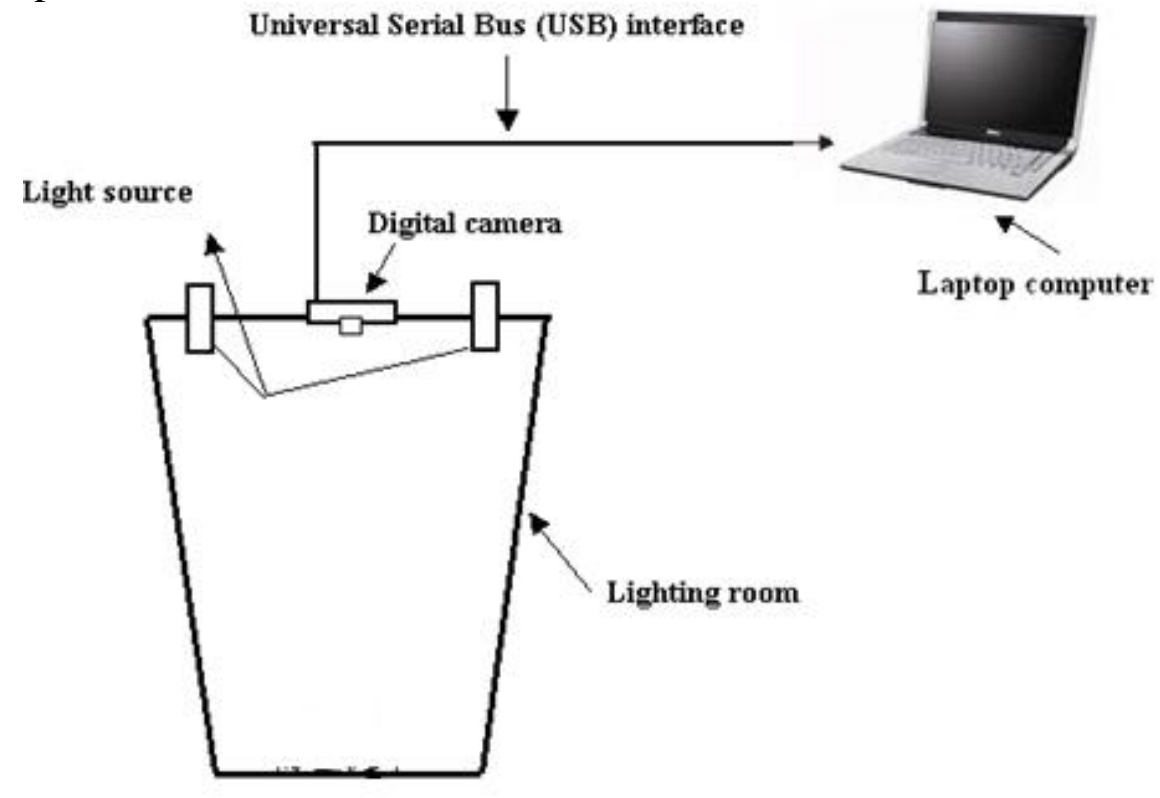

Fig. (4). Lighting box for capture the dried grapes images

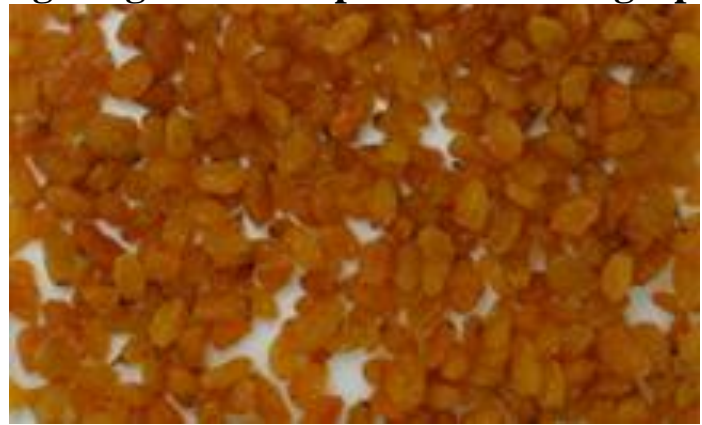

Fig. (5). Image of the dried grapes

The Lightness, $a$, and $b$ in the Histogram Window are not standard color values, where the $\mathrm{L}^{*}, \mathrm{a}^{*}$ and $\mathrm{b}^{*}$ coordinate axis defines the three 
dimensional CIE color space (Kortei et al., 2015). Thus L, a and b can be converted to $\mathrm{L}^{*}, \mathrm{a}^{*}$ and $\mathrm{b}^{*}$ values using the following formulas (Yam and Papadakis, 2004):

$$
\begin{aligned}
& \mathrm{L}^{*}=\frac{\text { Lightness }}{255} \times 100 \\
& a^{*}=\frac{240 a}{255}-120 \\
& b^{*}=\frac{240 b}{255}-120
\end{aligned}
$$

The total color change of the dried grapes in comparison to color values of fresh grapes having color values of $\mathrm{L}^{* *}, \mathrm{a}^{* *}$ and $\mathrm{b}^{* *}$ was symbolized by $\Delta \mathrm{E}$. The $\Delta \mathrm{E}$ parameter is calculated (Mohammadi et al., 2008; Saricoban and Yilmaz, 2010; Gorjian et al., 2011) as follows:

$$
\Delta E=\left[(\Delta L *)^{2}+(\Delta a *)^{2}+(\Delta \boldsymbol{b})^{2}\right]^{0.5}
$$

Where, $\mathrm{L}^{*}$ is lightness of dried grapes, $\mathrm{L}^{* *}$ is lightness of fresh grapes, $\mathrm{a}^{*}$ is redness of dried grapes, $\mathrm{a}^{* *}$ is redness of fresh grapes, $\mathrm{b}^{*}$ is yellowness of dried grapes and $\mathrm{b}^{* *}$ is yellowness of fresh grapes. $\Delta \mathrm{L}^{*}$ $=$ Lightness difference $=\mathrm{L}^{*} \mathrm{~L}^{* *}, \Delta \mathrm{a}^{*}=\mathrm{a}^{*} \mathrm{a}^{* *}$ and $\Delta \mathrm{b}^{*}=\mathrm{b}^{*} \mathrm{~b}^{* *}$. The positive values of $b^{*}$ indicate the yellow color, so, the dried grape which has high value of $b$, indicated good quality (Lokhande et al., 2017). There is no color standard for dried grapes. Therefore, color properties of fresh grapes were accepted as reference values (Aktas et al., 2008).

The hue angle $\left(\mathrm{H}^{\circ}\right)$ as a color parameter, describes the relative amounts of redness and yellowness where $0 \% / 360^{\circ}$ is defined for red/magenta, 90 ${ }^{\circ}$ for yellow, $180^{\circ}$ for green and $270^{\circ}$ for blue color. A lower hue value indicates a redder product (Pedisic et al., 2009). The hue angle could be calculated according to the following equations (LópezCamelo and Gómez, 2004; Dong et al., 2013):

Hue angle $=\mathrm{H}^{\circ}=\tan ^{-1}\left(\mathrm{~b}^{*} / \mathrm{a}^{*}\right)$.

When $\mathrm{a}^{*}<0, \quad \mathrm{H}^{\circ}=180+\tan ^{-1}\left(\mathrm{~b}^{*} / \mathrm{a}^{*}\right)$

Chroma as a color parameter indicates the purity or saturation of the color. It could be calculated according to the following equation (LópezCamelo and Gómez, 2004):

Chroma $=\left(a^{* 2}+b^{* 2}\right)^{0.5}$ 
Browning index (BI) as a color parameter, represents the purity of brown color and is considered as an important parameter associated with browning (Mohammadi et al., 2008). The browning index could be calculated according to (Dadali et al., 2007) as follows:

$$
\begin{gathered}
\quad B I=\frac{[100(x-0.31)]}{0.17} \ldots \ldots \ldots . . . \\
\text { Where } \mathrm{x}=\frac{\left(\mathrm{a}^{*}+1.75 \mathrm{~L}^{*}\right)}{\left(5.645 \mathrm{~L}^{*}+\mathrm{a}^{*}-3.012 \mathrm{~b}^{*}\right)}
\end{gathered}
$$

\section{c. Biogas burner efficiency}

The heat energy gained from combusting of biogas $\left(E_{\text {methane }}\right)$ can be calculated from the following equation (Mohammed, 2016):

$$
\boldsymbol{E}_{\text {methan }}=\boldsymbol{V}_{\text {bigas }} \times \boldsymbol{R}_{m} \times \boldsymbol{H}_{v} \times \boldsymbol{\eta}_{\text {comp }}
$$

Where, $V_{\text {biogas, }}$, is the biogas flow rate in $\mathrm{m}^{3}, \mathrm{R}_{\mathrm{m}}$, is the percentage of methane gas in decimal, $\mathrm{H}_{\mathrm{v}}$ is the calorific value of methane gas in $\mathrm{MJ} / \mathrm{m}^{3}$ and, $\eta_{\text {comp., }}$ is the combustion efficiency in decimal. In this study, the biogas flow rate was $0.9 * 4=3.6 \mathrm{~m}^{3} / \mathrm{h}$, the percentage of methane gas was 0.6 , the calorific value of methane gas was $25 \mathrm{MJ} / \mathrm{m}^{3}$ and the combustion efficiency was assumed to be $32.26 \%$ (Shrestha, 2001).

The heat energy for air $\left(\mathrm{E}_{\mathrm{air}}\right)$ can be calculated from the following equation (Mohammed, 2016):

$$
E_{a i r}=m_{a i r s} \times C p_{a i r} \times \Delta T
$$

Where $\mathrm{m}_{\text {air }}$, is the air flow rate in $\mathrm{m}^{3} / \mathrm{s}, \mathrm{Cp}_{\text {air }}$, is the specific heat of air $\left(1.005 \mathrm{~kJ} / \mathrm{kg} .{ }^{\circ} \mathrm{K}\right)$ and $\Delta T$ is difference between ambient air and air temperature after hating (Ti-To). The biogas burner efficiency (BBE, \%) could be calculated as follows:

$$
B B E=\frac{E_{a i r}}{E_{\text {melhane }}} \times 100
$$

\section{RESULTS AND DISCUSSION}

\section{Temperatures and relative humidity distributions}

The temperature distribution versus drying time is shown in Fig. (6) and the average temperatures during the experimental work in the biogas 
dryer are shown in Fig. (7). For Ti, To, Tdi, Tdo and Tdc the average values were $20.81,65.40,63.89,50.20$ and $51.98^{\circ} \mathrm{C}$, respectively .

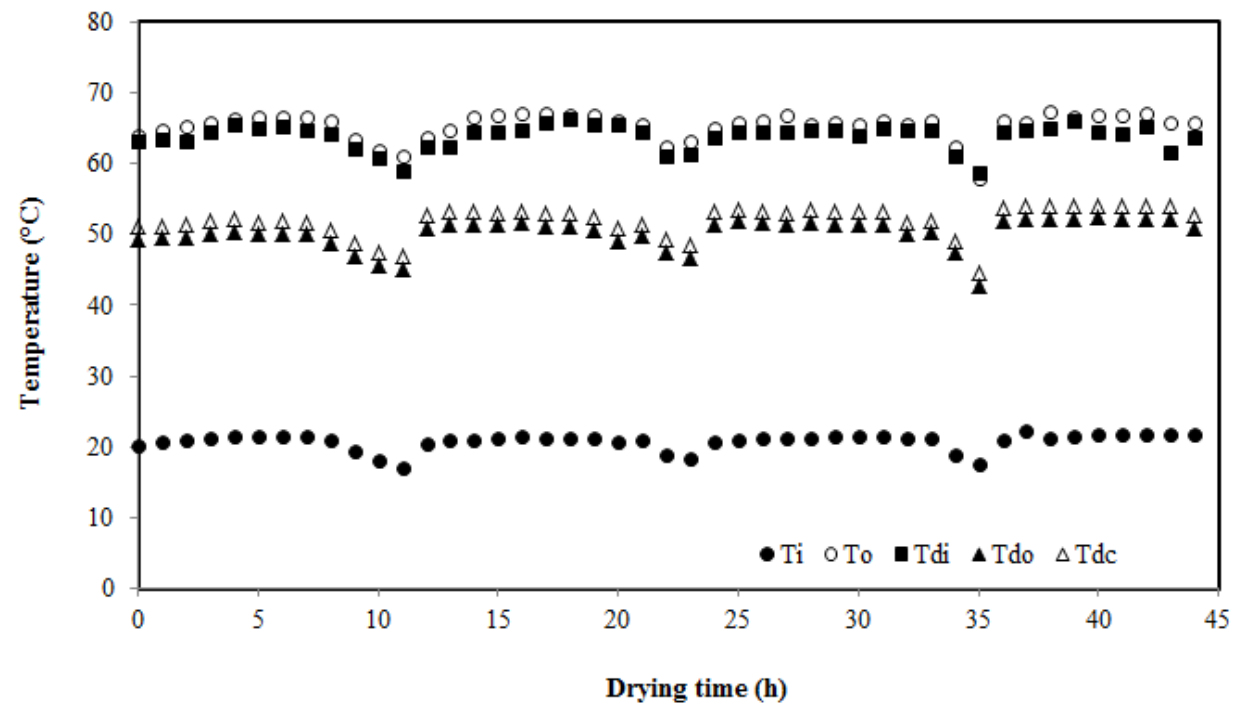

Fig. (6). Temperature distribution versus drying time.

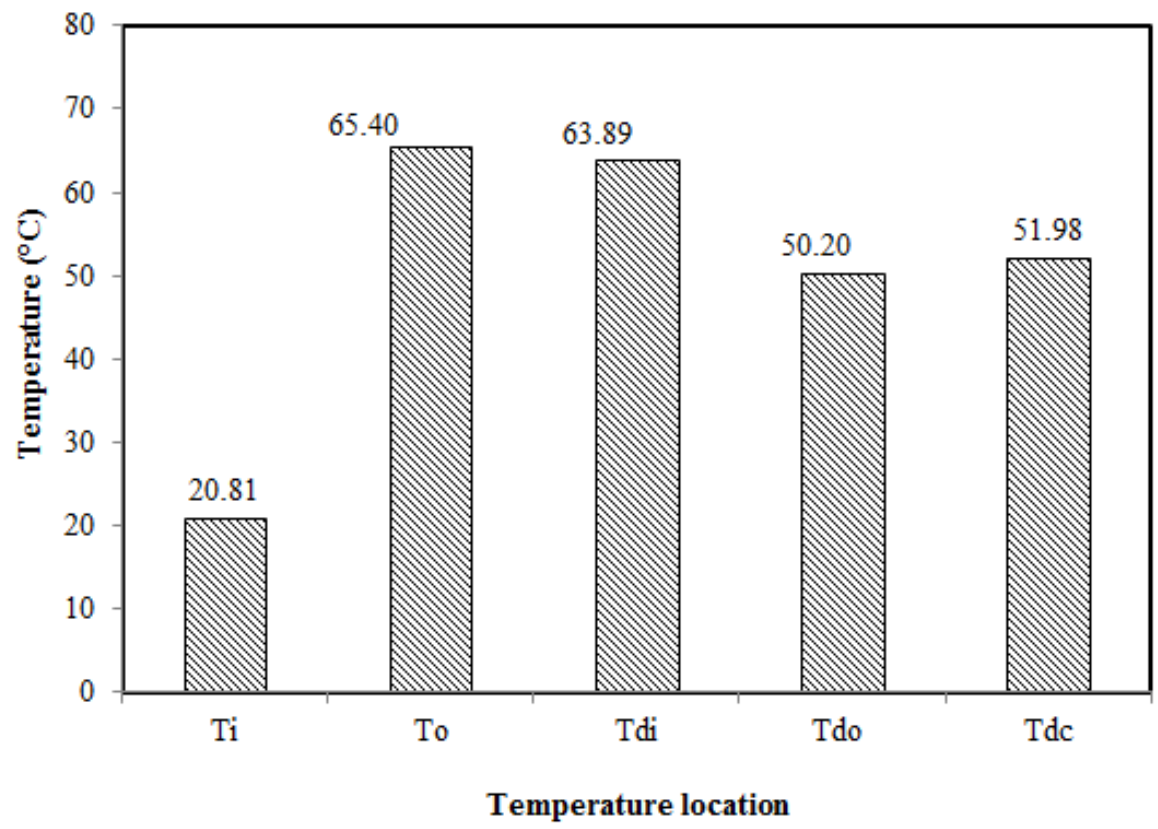

Fig. (7). Average values of temperature distribution (Ti,To, Tdi, Tdc and Tdo). 
The temperature (Tdi) was less than the temperature (To) by one Celsius. This difference is due to heat losses from the transmitting pipe. Thus during the operating of the biogas burning system, the drying air temperature was increased above the ambient air temperature due to energy gained from the heating system. This increasing in air temperature resulting in increasing the drying air temperature inside the drying chambers (Tdc) and it was around $51.98{ }^{\circ} \mathrm{C}$ as shown in Fig. (7). The difference between Tdi and Tdc is approximately $12^{\circ} \mathrm{C}$. This difference was due heat used in the grape drying in the chamber. The air was left the drying chamber at ( Tdo) around $50.20{ }^{\circ} \mathrm{C}$ as shown in Fig. (7). There is small difference between Tdc and Tdo which is approximately $2{ }^{\circ} \mathrm{C}$.

The relative humidity of air inside and outside the drying chamber versus drying time is shown in Fig. (8) and the average is shown in Fig. (9). It was clear that the average air relative humidity inside the drying chamber is lower than outside and such result was seen in the drying experiments of Yuwana and Sidebang (2016) as who study the performance of the hybrid solar-biomass dryer for fish drying and found that the air relative humidity inside the drying chamber is lower than outside. Additionally, Kaveh et al. (2015) reported that during the drying experiments, relative humidity was decreased over time at different locations inside the dryer.

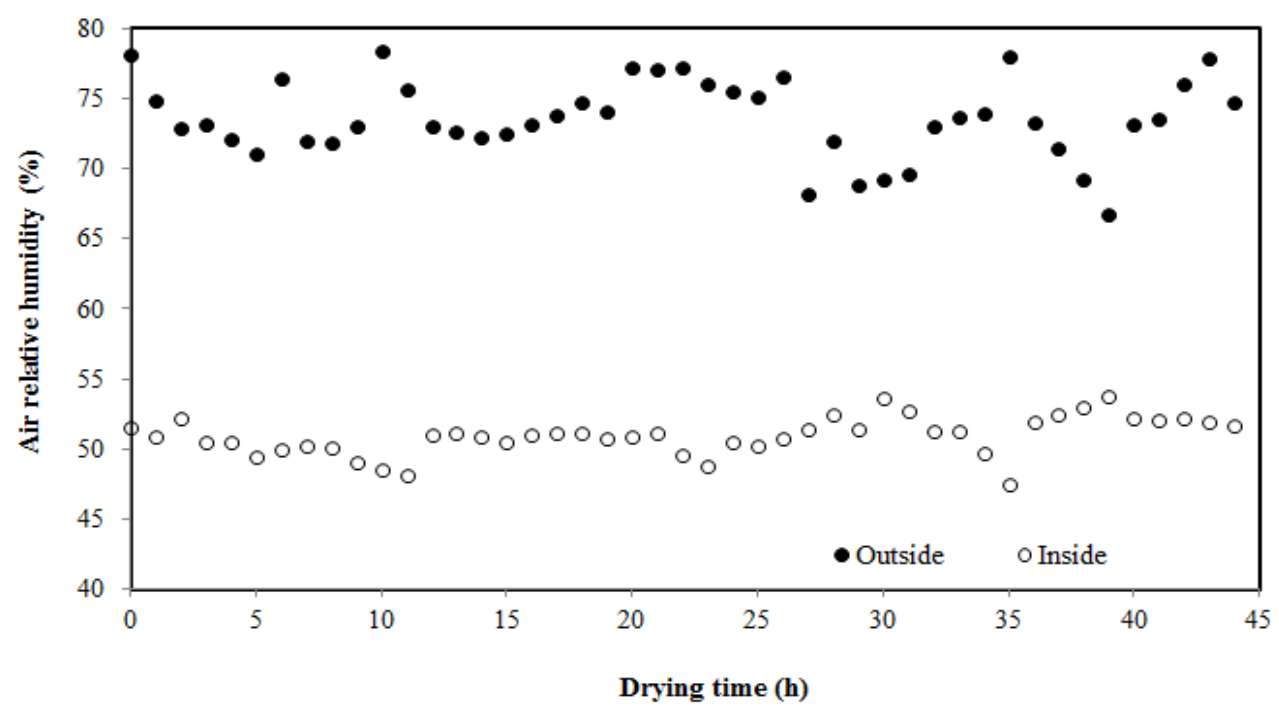

Fig. (8). Air relative humidity inside and outside the drying chamber versus drying time. 


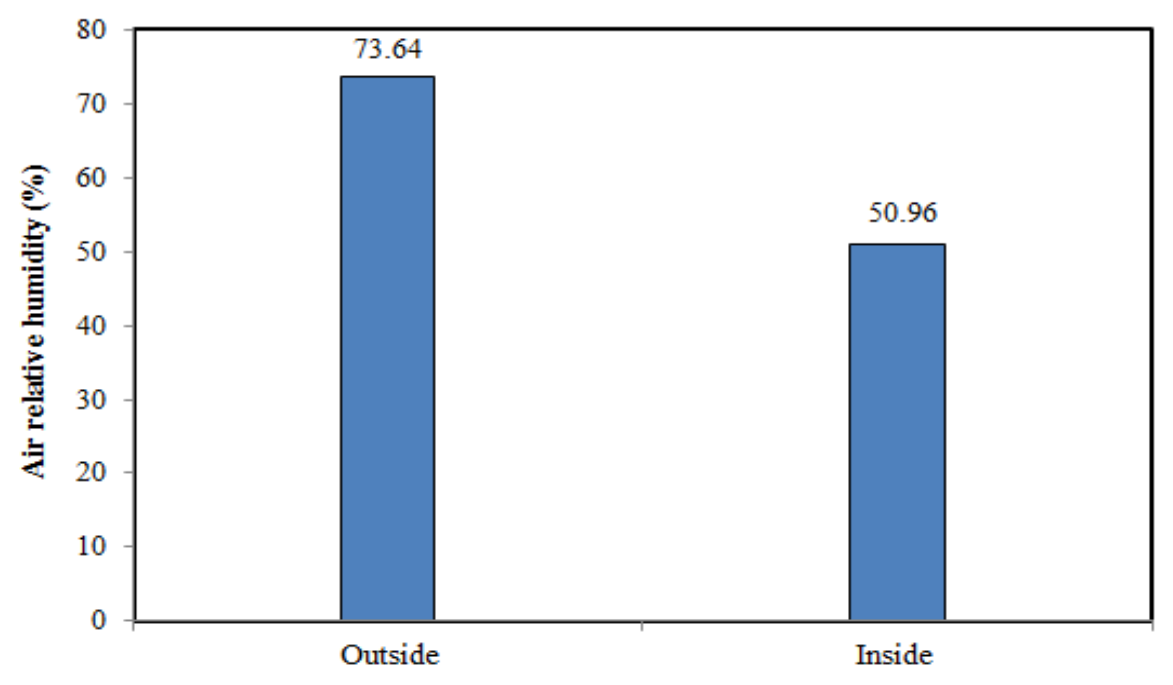

Location of measurement

Fig. (9). The air relative humidity related to location measurement.

\section{Drying Characteristics}

The initial moisture content of the grapes was appeared as $79 \%$ (on wet base) during drying experiments in the biogas dryer. After drying, the final moisture contents were reduced to approximately $14 \%$ (wet base). Fig. (10) shows the experimentally average moisture content of seedless grapes versus drying time for treated grapes with sodium hydroxide prior to biogas drying method. It was clear that an abruptly drop in the moisture content with drying time occurred, thus, the constant rate drying period is not existed using the biogas dryer. The drying process took place in the falling rate period and the moisture content decreases continuously with drying time. These results agree with the observations of Yaldiz et al. (2001), Tulasidas et al. (1993) and Pangavhane et al. (1999). The treated grapes took less time about $44 \mathrm{hrs}$. However, dipping in hot water or the use of chemicals such as sodium hydroxide increase drying rate (Bingol et al., 2008; Shi et al., 2008).

\section{Biogas burner efficiency}

The heat energy gained from combusting of biogas was equal to 3.6 $\left(\mathrm{m}^{3} / \mathrm{h}\right) * 0.6 * 25\left(\mathrm{MJ} / \mathrm{m}^{3}\right)^{*} 0.3226 * 1000=17388 \mathrm{~kJ} / \mathrm{h}$. In this study, the air 
flow rate was $3.14 *(4 * 2.5 / 100) \wedge 2 / 4 \quad\left(\mathrm{~m}^{2}\right) * 1.21 \quad \mathrm{~m} / \mathrm{s} * 1.27$ $\mathrm{kg} / \mathrm{m}^{3} * 3600=34.2 \mathrm{~kg} / \mathrm{h}$ and $\Delta T=65-21=44^{\circ} \mathrm{C}+273=317{ }^{\circ} \mathrm{K}$, so $\mathrm{E}_{\text {air }}=$ $34.2 \quad(\mathrm{~kg} / \mathrm{h}) \quad * 1.005 \quad\left(\mathrm{~kJ} / \mathrm{kg} .{ }^{\circ} \mathrm{K}\right) * 314 .{ }^{\circ} \mathrm{K}=10790.8 \mathrm{KJ} / \mathrm{h}$, thus, $\mathrm{BBE}=10790.8 / 17388=62.06 \%$, however, Mohammed (2016) obtained biogas burner efficiency of $57 \%$ in the drying experiments.

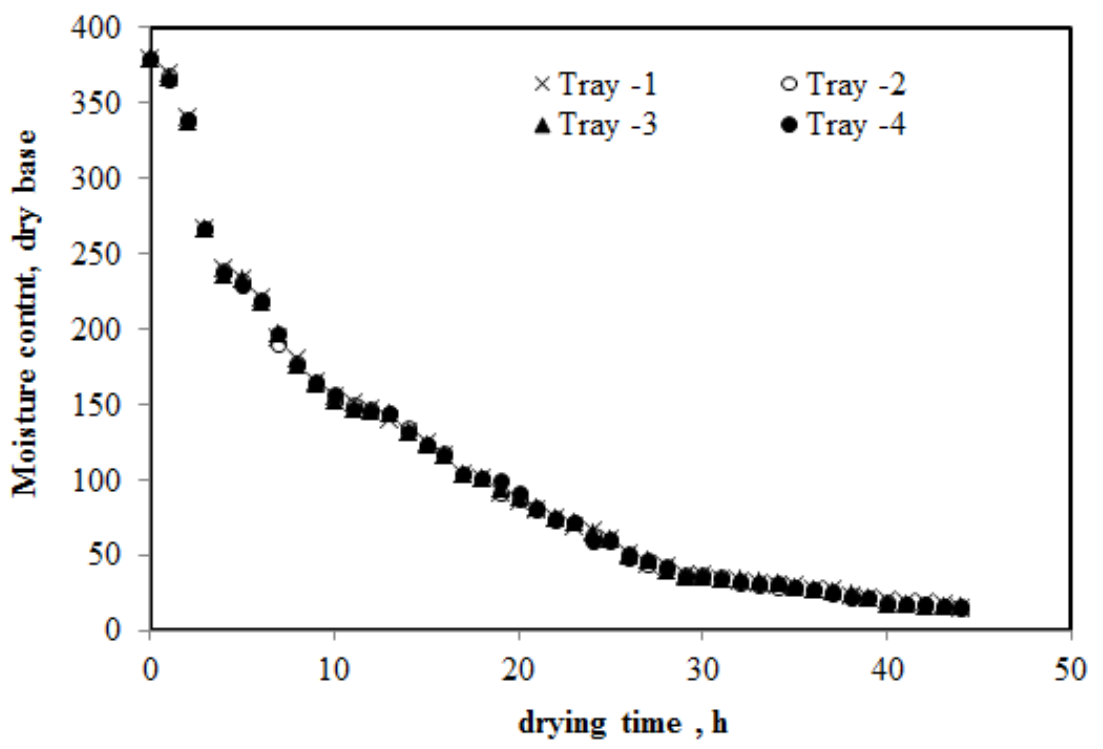

Fig. (10). Average experimentally moisture content versus drying time for four trays inside the drying chamber.

\section{Raisins color quality}

Table (2) shows the mean values of color parameters $\left(\mathrm{L}^{*}, \mathrm{a}^{*}\right.$ and $\mathrm{b}^{*}$ ), Chroma, browning index, hue angle for the fresh and the dried grapes. The values of lightness ( $\mathrm{L}^{*}$-value), red/green ( $\mathrm{a}^{*}$-value) and yellow/blue ( $\mathrm{b}^{*}$ value) were $73.73,-14.92$ and 43.50 , respectively for the fresh grapes as shown in Table (4). These findings are in agreement to those reported by Dong et al. (2013) for fresh Thompson seedless grapes as their parameters values were $73.89,71.78$, and 76.32 for $L^{*},-17.63,-17.18$ and -18.19 for $\mathrm{a}^{*}$ and $40.33,39.45$ and 43.52 for $\mathrm{b}^{*}$.

In this study, after drying grapes there was a general reduction in lightness ( $\mathrm{L}^{*}$-values), which was 52.12. However, $\mathrm{L}^{*}$ values were reduced from 35 to around 16 during hot air drying of the grapes (Khazaei et al., 2013). Moreover, Doymaz and Pala (2002) reported the $\mathrm{L} *$ values were around 18 for final dried grape at different air 
temperatures. Additionally, in sun dried raisin samples, $\mathrm{L}^{*}$ values were ranged from 15.94 to 35.91 (mean 27.72) as reported by Şevik et al. (2014). Besides, value of $L^{*}$ (lightness) for dried grapes dipped in olive oil and potassium carbonate solution was the highest (23.55) at air velocity of $1 \mathrm{~m} / \mathrm{s}$ and $70^{\circ} \mathrm{C}$ for drying air temperature (Chayjan et al., 2011).

Table (2). Mean of color parameters $\left(\mathrm{L}^{*}, \mathbf{a}^{*}, \mathbf{b}^{*}, \Delta \mathrm{E}\right.$, Chroma, browning index and hue angle) of the dried grapes in comparison to the fresh grapes.

\begin{tabular}{|l|c|c|}
\hline \multicolumn{1}{|c|}{ Color parameters } & Fresh grapes & Dried grapes \\
\hline $\mathrm{L}^{*}$ & 73.73 & 52.12 \\
\hline $\mathrm{a}^{*}$ & -14.92 & 4.89 \\
\hline $\mathrm{b}^{*}$ & 43.5 & 13.98 \\
\hline total color change $(\Delta \mathrm{E})$ & 0.00 & 41.67 \\
\hline Chroma & 45.99 & 14.82 \\
\hline Browning index & 72.66 & 43.52 \\
\hline Hue angle & 108.2 & 70.65 \\
\hline
\end{tabular}

The red/green ( $\mathrm{a}^{*}$-values) increased after drying process and was ranged between 4.89 as shown in Table (4) Monsalve-Gonzalez et al. (1993) reported an increase in $\mathrm{a}^{*}$ values after drying and this was considered to be an indicator for browning of the dried samples. Additionally, in sun dried raisin samples, $a^{*}$ values were ranged from 7.40 to 13.88 as reported by Şevik et al. (2014).

The yellow/blue ( $\mathrm{b}^{*}$-values) decreased and was 13.98 as shown in Table (4) For the dried grapes, $b^{*}$ values were ranged from 6.29 to 20.74 as reported by Şevik et al. (2014).

Total color difference, $\Delta \mathrm{E}$, is a colorimetric parameter extensively used to characterize the variation of colors depending on processing conditions (Maskan, 2001). In this study, $\Delta \mathrm{E}$ values were calculated after the drying period. A larger $\Delta \mathrm{E}$ indicates greater color change from the fresh grapes (Saricoban and Yilmaz, 2010). In this study, it was 41.67 as shown in Table (4) and this could be due to the absence of water in the capillary voids of the dried grapes (Kortei, et al., 2015). This result is in agreement 
with data of Dong et al. (2013), who reported total color change value for the dried grapes to be $50.41,46.54$ and 44.08 based on air temperature. The observed value of Chroma at the end of the drying period was 14.82as shown in Table (4); meanwhile, value of Chroma for fresh grapes was 45.99. There was a general decrease in Chroma values. This result is in agreement with data of Dong et al. (2013), who reported Chroma value for fresh Thompson seedless grape of 43.62, 43.03 and 47.17 and for the dried grapes, these values were $8.56,7.51$ and 17.20 which obtained at air temperatures of $30^{\circ} \mathrm{C}, 35^{\circ} \mathrm{C}$ and $40^{\circ} \mathrm{C}$, respectively. According to Goncalves et al. (2007), lower Chroma value indicates an increase in tonality of the grapes color. Moreover, the Chroma values were ranged for dried grapes from 9.71 - 24.28 as reported by Şevik et al. (2014).

The observed value of hue angle at the end of the drying period was 70.65 as shown in Table (4). There was a general decrease in the hue angle value after grapes drying. These results are in agreement with data of Dong et al. (2013). They reported the hue angle value for fresh Thompson seedless grape of $112.41,113.53$ and $112.68^{\circ}$ and for the dried grapes of $58.67,93.9$ and $54.08^{\circ}$. The hue angle range in the dried grapes in this study was within the $90^{\circ}$ region which suggests an apparent reddish yellow color (Pedisic et al., 2009). Additionally, in sun dried raisin samples hue angle values ranged from 39.62 to 69.72 (mean 51.58) as reported by Şevik et al. (2014). In this study, the hue angle value was found to be high for biogas dried samples compared to other grapes dried by other methods.

The browning index was used to describe quantitatively the color variation of the raisin produced by the biogas dryer (Wang et al., 2017). In this study, the browning index was 43.52 as presented in Table (2) . However, Wang et al. (2017) obtained values of browning index of $70.35,66.49,54.66,46.76,33.50$ and 30.48 of the dried Thomson seedless based on berry ripeness.

\section{CONCLUSION}

A biogas dryer was designed, fabricated and tested. Drying kinetics of Thompson seedless grapes is evaluated experimentally. Thompson seedless grapes were dried in forced convection heat transfer mode from initial moisture content of $79 \%$ (wb) to final moisture content $14 \%$ (wb) in 44 
hours. The drying experiments were carried out under uncontrolled conditions of environment. The biogas burner efficiency was found to be $62.06 \%$.

\section{REFERENCES}

Adobe Systems (2002). Adobe Photoshop 7.0.User Guide. San Jose, CA: Adobe Systems Inc.

Aktas, T.; Ulger P.; Daglioglu F. and Hasturk F. (2008). Effect of storage time on quality of plum osmotically pretreated with trehalose and sucrose solutions before drying. Proc. 10th International Congress on Mechanization and Energy in Agriculture, Antalya, Turkey, 904-909.

Alemneh, Z. (2011). The contribution of biogas production from cattle manure at household level for forest conservation and soil fertility improvement. Unpublished MSc Thesis, Science Faculty, Addis Ababa University.

Athanasopoulos, P. and Thanos A. (1998). Quality characteristics of sultanina table grapes store in pilot plant scale. Fruits, 53: 199-206.

Azzouz, S.; Guizani A.; Jomaa W. and Belghith A. (2002). Moisture diffusivity and drying kinetic equation of convective drying of grapes. Journal of Food Engineering, 55 (4): 323-330.

Baral, S.; Pudasaini S. P.; Khanal S. N. and Gurung D. B. (2013). Mathematical modeling, finite element simulation and experimental validation of biogas-digester slurry temperature. International Journal of Energy and Power Engineering, 2(3):128-135.

Bingol, G.; Roberts J. S.; Balaban M. O. and Devres Y. O. (2012).Effect of dipping temperature and dipping time on drying rate and color change of grapes. An International Journal, 30(6):597-606.

Brennand, C.P. (1994). Home drying of food. August 1994 (FN-330) http://extension.usu.edu/files/publications/publication/FN-330.pdf

Chayjan, R.; Peyman M. H.; EsnaAshari M. and Salari K. (2011). Influence of drying conditions on diffusivity, energy and color of seedless grape after dipping process. AJCS, 5(1): 96-103.

Corrêia, A. F.; Godoy A. C.; Siqueira J. A. C. ; Feiden A. and Soares C. M. T. (2016). Evaluation of biogas calorific potential for use in medicinal plant dryers. Energ. Agric., Botucatu, 31(2):163-168. 
Cvetkovic, S.; Radoicic K. T.; Vukadinovic B. and Kijevcanin M. (2014). Potentials and status of biogas as energy source in the Republic of Serbia. Renewable and Sustainable Energy Reviews, 31:407-416.

Dadali, G., Apar D.K.; Ozbek B. (2007). Color change kinetics of okra undergoing microwave drying. Drying Technology, 25: 925-936.

Di Matteo, M.; Cinquanta L.; G. Galiero and Crescitelli S. (2000).Effect of a novel physical pretreatment process on the drying kinetics of seedless grapes. Journal of Food Engineering, 46 (2):83-89.

Dong, Y.; Zhang R.; Zhang Z.; Yang L.; Xue C.; Wei J. and Yang R. (2013). Study on kinetics of color changes in thompson seedless grapes during drying process. Advanced Materials Research, Vols. (726-731):456-462.

Doymaz, I. and Pala M. (2002). The effects of dipping pretreatments on airdrying rates of the seedless grapes. Journal of Food Engineering, 52 (4):413-417.

El-Shimi, S.A. (1994). Biogas production and utilization in rural Egypt. Activities and Achievement of Agricultural Research Center. Seminar on Biological N-Fix Associated with Cereal Crops, Giza, Egypt, Sept. 26-28.

El-Bakhshwan, M.K.; Abd El-Ghafar S.M.A., Zayed M.F. and ElShazly A.E. (2015).Effect of mechanical stirring on biogas production efficiency in large scale digesters. J. Soil Sci. and Agric. Eng., Mansoura Univ.,6 (1):47-63.

Ghanem, T.H. (2002). Drying onion using a solar dryer with an auxiliary heating system. The $10^{\text {th }}$ Conference of the Misr of Ag. Eng. Socitey, 16-17 October,2002:315-326.

Gonçalves B.; Silva A.P.; Moutinho- Pereira J.; Bacelar E.; Rosa E. and Meyer, S.A. (2007). Effect of ripeness and postharvest storage on the evolution of colour and anthocyanins in cherries (Prunusavium L.). Food Chem., 103: 976- 984.

Gorjian, Sh.; TavakkoliH.,T.; Khoshtaghaza M. H. and Nikbakht A. M. (2011). Drying kinetics and quality of barberry in a thin layer dryer. J. Agr. Sci. Tech., 13: 303-314. 
Hahn, F.; Hernandez G.; Hernandez J.; Perez C. and Vargas J.M. (2011). Optimization of Roselle drying time and drying quality. Canadian Biosystems Engineering, 53: 3.13.8.

Helmy, M.A.; Abd EL-Rhman A.A.; Ebaid M.T. and Hassan M.A. (2003). Expectant production of biogas and fertilizer from different residues fermentation using biogas unit. Misr J.Ag.Eng.,20(4): 949964.

Karathanos, V. T. and Belessiotis V. G. (1999). Application of a thin-layer equation to drying data of fresh and semi-dried fruits.J. agric. Engng Res., 74: 355-361.

Kassem, S.S. (2007). Solar drying of grapes. MSc Thesis, Agricultural Engineering Department, Faculty of Agriculture, Alexandria University, Egypt.

Kaveh, M.; Chayjan R.A. and Esna-Ashari M. (2015). Thermal and physical properties modelling of terebinth fruit (Pistacia atlantica L.) under solar drying. Res. Agr. Eng., 61(4):150-161.

Khazaei, N.B.; Hashjin T.T.; Ghassemian H.; Khoshtaghaza M.H. and Banakar A. (2013). Application of machine vision in modeling of grape drying process. Agr. Sci. Tech., 15:1095-1106.

Kortei, N.K.; Odamtten G.T.; Obodai M.; Appiah V. and Akonor P.T. (2015). Determination of color parameters of gamma irradiated fresh and dried mushrooms during storage. Croatian Journal of Food Technology, Biotechnology and Nutrition, 10 (1-2):66-71.

Lantz, M.; Svensson M.; Bjornsson L. and Borjesson P. (2007). The prospects for an expansion of biogas systems in Sweden-Incentives, barriers and potentials. Energy Policy, 35:1830-1843.

Lokhande, S. M.;Ranveer R. C.; Sahoo A. K. (2017). Effect of microwave drying on textural and sensorial properties of grape raisins. International Journal of ChemTech Research, 10 (5):938-947.

LópezCamelo, A. F. L. and Gómez P.A. (2004). Comparison of color indexes for tomato ripening. HorticulturaBrasileira, Brasília, 22(3):534-537.

Maskan, M. (2001).Kinetics of color change of kiwifruits during hot air and microwave drying. Journal of Food Engineering, 2001, 48:169-175. 
Mohammadi, A.; Rafiee S.; Emam-Djomeh Z. and Keyhani A. (2008). Kinetic models for color changes in kiwifruit slices during hot air drying. World Journal of Agricultural Sciences, 4 (3): 376-383.

Mohammed, E.M.Y. (2016). Utilization of biogas thermal energy assisted solar dryer for drying grapes. MSc. Thesis, Mansoura University, Faculty of Agriculture, Agricultural Engineering Department, Egypt.

Monsalve-Gonzalez, A.; Barbosa-Cánovas, G.V.; Cavalieri, R.P.; McEvily, A. and Iyengar, R. (1993). Control of browning during storage of apple slices preserved by conditions on quality and shelf life of fresh-cut pineapple (Ananascomosus). Postharvest Biology and Technology, 50: 182-189.

Moy, J.H.; Yang P.Y. and Miyake L. (1985). A solar-biogas system for food drying. In AGRIS since 1987.

Oztekin, S.; Bascetincelik A. and Soysal Y. (1999). Crop drying programme in Turkey. Renewable Energy, 16:789-794.

Pangavhane, D.R. and Sawhney R.L. (2002). Review of research and development work on solar dryers for grape drying. Energy Conversion and Management, 43 (1): 45-61.

Pangavhane, D.R.; Sawhney R.L. and Sarsavadia P.N. (1999). Effect of various dipping pretreatment on drying kinetics of Thompson seedless grapes. Journal of Food Engineering, 39(2): 211-216.

Pangavhane, D.R.; Sawhney R.L. and Sarsavadia P.N. (2002). Design, development and performance testing of a new natural convection solar dryer. Journal of Energy, 27 (6): 579-590.

Pastorek, Z.; Kára J. and Jevič P. (2004). Biomasa - obnovitelný zdroj energie. Renewable Source of Energy. Prague, Fcc Public.

Pedisic, S.; Levaj B.; Dragovic- Uzelac V.; Skevin D. and SkendrovicBabo M. (2009) Color parameters and total anthocyanins of sour cherries (Prunuscerasus L.) during ripening. Agriculture Conspectus Scientificus, 74 (3): 259-262.

Ramos, I.N.; Brandao T.R.S. and Silva C.L.M. (2015). Simulation of solar drying of grapes using integrated heat and mass transfer model. Renewable Energy, 81:896-902. 
Rihan, J.I. (2013). Agricultural residues and biogas production in rural Egypt (a case study of biogas project in Kafr El- Amir Village, El Dakhlia Governorate). J. Agric. Econom. and Social Sci., Mansoura Univ.,4(1):123 - 140.

Saricoban, C. and Yilmaz M.T. (2010). Modelling the effects of processing factors on the changes in colour parameters of cooked meatballs using response surface methodology. World Applied Sciences Journal, 9 (1): 14-22.

Şevik, R.; Şen L. and Nas S. (2014). Determination of color quality and HMF content of unprocessed sultanas obtained from different vineyards. International Journal of Research in Agriculture and Food Sciences, 2(5):32-42.

Sharma, P.C.; Sharma K.D. and Parashar R.S. (1992). Prospects of raisin production in tribal areas of Himachat Paradesh. Indian Food Packer, 16-19.

Shi, J.; Pan Z.; Mchugh T.H.; Wood D.; Zhu Y.; Avena-Bustillos R.J. and Hirschberg E. (2008). Effect of berry size and sodium hydroxide pretreatment on the drying characteristics of blueberries under infrared radiation heating, Journal of Food Science, 73(6):E259- E265.

Shrestha, J.N. (2001). A Study Report on Efficiency Measurement of Biogas, Kerosene and LPG Stoves. Submitted to: Biogas Support Program Lalitpur, Nepal Submitted by: Center for Energy Studies Institute of Engineering Tribhuvan University Pulchowk, Lalitpur July 2001.

Sona, V.P. (2015). Solar tunnel drier combined with biogas for copra drying. International Research Journal of Engineering and Technology (IRJET) ,2(4): 882-885.

Tlay, R.; Tohleh M.Kh. and Mohammad M. (2014). The effect of sulphur dioxide $\left(\mathrm{SO}_{2}\right)$ and drying methods in chemical and bioactive indicators and antioxidant activity in local yellowish Baladi grape. Damascus University Journal of agricultural sciences, 30(2):211-224(In Arabic).

Tulasidas, T.N.; Raghavan G.S.V. and Norris E.R. (1993). Microwave and convective drying of grapes. Transaction ASAE, 36 (6): 18611865 . 
Wang, J.; Mu W.-S.; Fang X.-M.; Mujumdar A.S.; Yange X.-H.; Xu L.Y.; Xie L.; Xiao H.-W.; Gao Z.-J.; Zhang Q. (2017). Pulsed vacuum drying of Thompson seedless grape: Effects of berry ripeness on physicochemical properties and drying characteristic. Food and Bio products Processing, 106:117-126

Yam, K.L. and Papadakis S.E. (2004). A simple digital imaging method for measuring and analyzing color of food surfaces. Journal of Food Engineering, 61:137-142.

Yuwana, Y. and Sidebang B. (2016). Performance testing of the hybrid solar-biomass dryer for fish drying. International Journal of Modern Engineering Research (IJMER),6(11):63-68.

\section{الملخص العربى}

\section{خصائص التجفيف للعنب البناتي صنف طومسون الخالي من البذور في طبقة} رقيقة باستخدام مجفف الغاز الحيوي

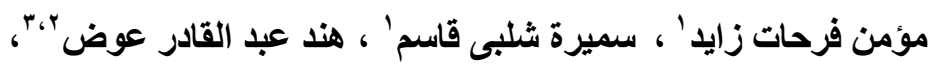

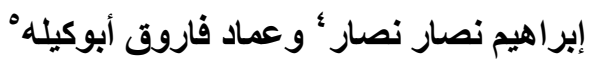

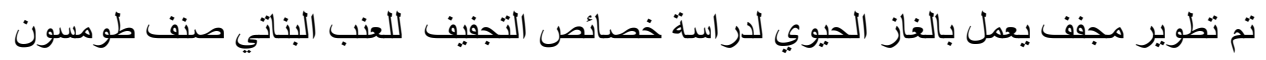

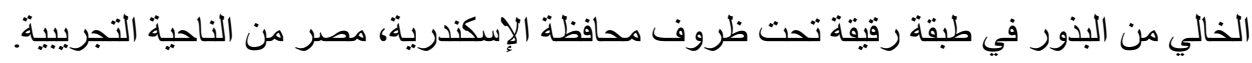

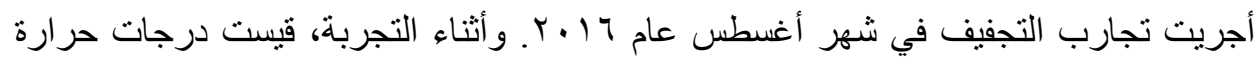

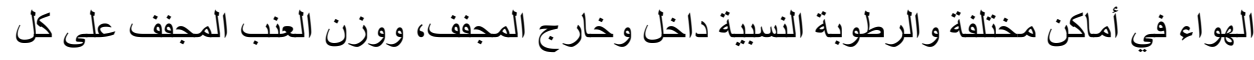

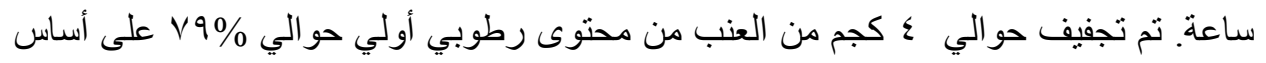

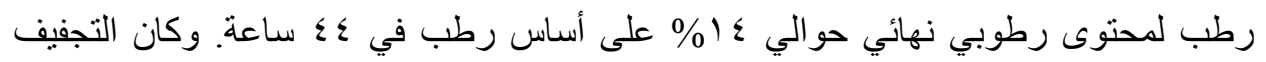

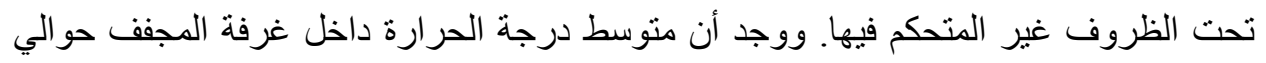

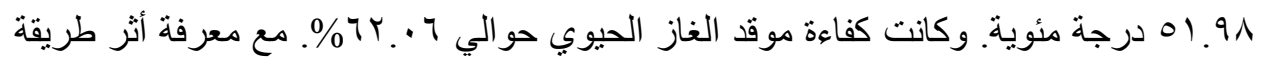

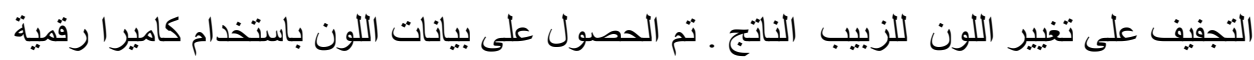

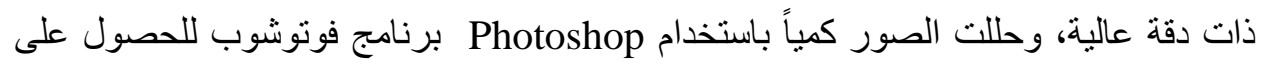

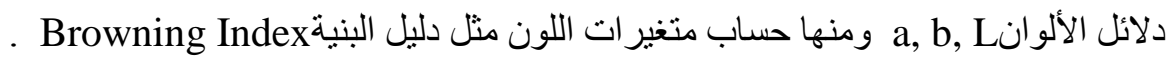

1باحث، معهد بحوث الهندسة الزراعية، مركز البحوث الزراعية، الدقي، جيزة، ج.م.ع

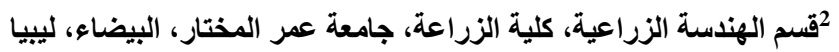

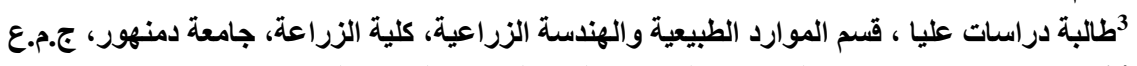

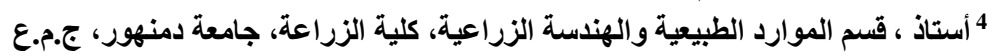

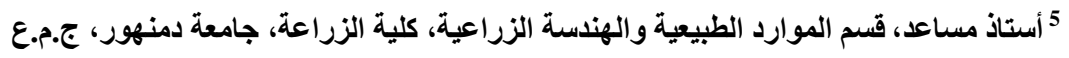




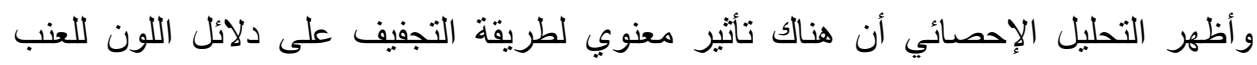

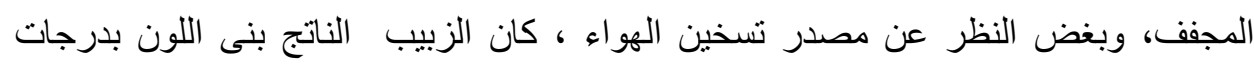

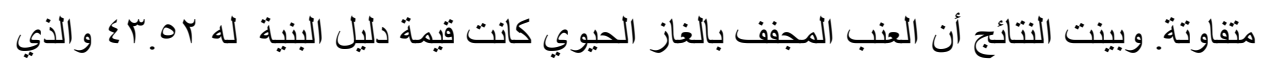

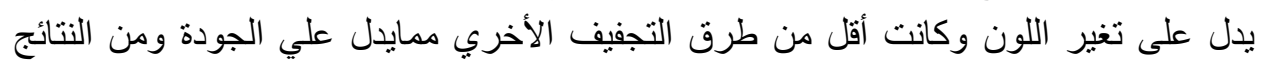

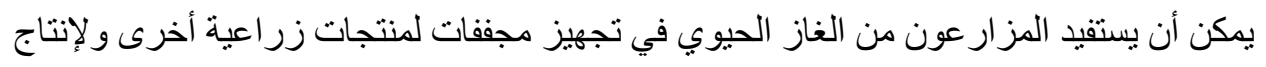
زبيب ذات نوعية جيدة . 